\title{
Grazing management strategies for massaigrass-forage peanut pastures. 3. Definition of sward targets and carrying capacity 1
}

\section{Carlos Mauricio Soares de Andrade ${ }^{2}$, Rasmo Garcia ${ }^{3}$, Judson Ferreira Valentim², Odilon Gomes Pereira ${ }^{3}$}

\footnotetext{
${ }_{1}$ Part of the Doctorate thesis of the first author, with financial support by Fapemig and Embrapa.

2 Embrapa Acre, CP 321, CEP: 69908-970, Rio Branco, AC.

${ }^{3}$ Animal Science Department, UFV, granted by CNPq.
}

\begin{abstract}
This study was carried out to define sward management targets for mixed Massaigrass (Panicum maximum $\mathrm{x}$ P. infestum, cv. Massai) and forage peanut (Arachis pintoi Ac 01) pastures in the Western Brazilian Amazon. Seasonal variation in the pasture carrying capacity was also analyzed. Pastures were intermittently stocked at three daily herbage allowance levels (9.0, 14.5 and $18.4 \%$ of live weight) from October 2002 to December 2003. Sward targets were defined in terms of the sward condition that best conciliated the grass-legume balance, the maintenance of the structure of Massaigrass tussocks and the equilibrium between forage production and utilization. For the Western Brazilian Amazon conditions, the following sward management targets can be recommended for mixed Massaigrass and forage peanut pastures under intermittent stocking: pregrazing height ranging from $50-55 \mathrm{~cm}$ (June to September) to $65-70 \mathrm{~cm}$ (October to May), and post-grazing height from 30$35 \mathrm{~cm}$ (June to September) to $35-40 \mathrm{~cm}$ (October to May). Annual carrying capacity of this mixed pasture in 2003 was 2.7 $\mathrm{AU} / \mathrm{ha}$. The average carrying capacity during the dry season $(1.8 \mathrm{AU} / \mathrm{ha})$ was $50 \%$ lower than that observed during the rainy season (3.6 AU/ha).
\end{abstract}

Key Words: Arachis pintoi, legume, Panicum maximum, sward structure, Western Amazon

\section{Estratégias de manejo do pastejo para pastos consorciados de capim- massai e amendoim forrageiro. 3. Definição de alvos de manejo e da capacidade de suporte}

\begin{abstract}
RESUMO - Este estudo foi conduzido com o objetivo de definir alvos de manejo do pastejo para pastagens consorciadas de capim-massai (Panicum maximum x P. infestum, cv. Massai) e amendoim forrageiro (Arachis pintoi Ac 01) na Amazônia Ocidental. Também foi analisada a variação sazonal da capacidade de suporte da pastagem. A pastagem foi submetida a três níveis de oferta diária de forragem $(9,0 ; 14,5$ e 18,4\% do PV), sob lotação rotacionada, entre outubro de 2002 e dezembro de 2003. A definição dos alvos de manejo foi baseada na condição da pastagem que melhor conciliou o equilíbrio da relação gramínea-leguminosa, a manutenção da estrutura das touceiras do capim-massai e o balanço entre a produção e a utilização da pastagem. Para as condições da Amazônia Ocidental, os seguintes alvos de manejo do pastejo podem ser recomendados para pastagens consorciadas de capim-massai e amendoim forrageiro sob lotação rotacionada: altura pré-pastejo de $50-55 \mathrm{~cm}$ (junho a setembro) ou $65-70 \mathrm{~cm}$ (outubro a maio) e altura pós-pastejo de $30-35 \mathrm{~cm}$ (junho a setembro) ou $35-40 \mathrm{~cm}$ (outubro a maio). A capacidade de suporte anual desta pastagem em 2003 foi de $2,7 \mathrm{UA} / \mathrm{ha}$. O valor médio durante o período seco (1,8 UA/ha) foi $50 \%$ menor que aquele verificado na média do período chuvoso $(3,6 \mathrm{UA} / \mathrm{ha})$.
\end{abstract}

Palavras-chave: Amazônia Ocidental, Arachis pintoi, leguminosa, Panicum maximum, estrutura do pasto

\section{Introduction}

The development of grazing management strategies for grass-legume pastures is an important step to ensure wide spread adoption of the technology; however, it is not a simple task (Valentim \& Andrade, 2004). Even in temperate countries, with a longer history of research in grass-legume pastures, there is a high degree of uncertainty about grazing management strategies to control species balance in mixed pastures (Hodgson \& Silva, 2000). Some factors that complicate the definition of grazing management strategies for grass-legume pastures include: a) competition for resources (light, water and nutrients) among species; b) differences related to reactions to grazing; c) differences related to animal preference; and, d) differences in reaction to climate variations (Spain, 1995; Lascano, 2000). In tropical regions, an additional difficulty in understanding and managing grass-legume pastures is the great diversity of 
forage species and morphological types, allowing a very high number of binary associations. These factors imply the need to develop specific grazing management strategies for each grass-legume association (Cruz \& Sinoquet, 1994; Thomas, 1995; Fisher et al., 1996).

Hodgson (1990) and Briske \& Heitschmidt (1991) showed that animal production under grazing is the result of the efficiency of three processes: (1) forage production, (2) forage consumption and (3) forage conversion in animal product. These authors also showed that the efficiency of the second process (utilization) is inversely related to the efficiencies of the two other processes. This is the reason why it is not possible to maximize, at the same time, pasture production and pasture utilization (Parsons et al., 1983), in the same way that it is not possible to maximize forage consumption per animal and forage consumption per unit area, simultaneously (Hodgson, 1990). Thus, the essence of grazing management is to reach a harmonic balance among the efficiencies of the three processes (Hodgson, 1990; Briske \& Heitschmidt, 1991). With grass-legume pastures another factor that needs to be considered is the maintenance of the botanical composition, especially legume persistence. This point is as important for pasture sustainability (Thomas, 1992, 1995; Boddey et al., 1997) as for animal performance, especially in the case of legumes showing high nutritional quality and palatability, such as Arachis pintoi (Lascano, 1995; 2000). Therefore, the definition of grazing management strategies for grass-legume pastures is a more complex task than for grass-only pastures.

The concept of sward state was proposed by Hodgson (1985) to define grazing management strategies for temperate pastures. According to this concept studies designed to define grazing management strategies should be based on control and manipulation of specific sward characteristics, either in steady state or following some specific pattern of variation. Hodgson (1985) also considered that variations in conventional management parameters such as stocking rate, grazing pressure and grazing cycle are now seen as part of the strategy to maintain target sward conditions rather than as the main grazing management strategy. Besides flexibility and capacity to integrate several important variables, such as regrowth mechanisms, sward structure, botanical composition and forage intake, grazing management based on sward targets also presents as positive attributes objectivity and easiness of practical application. In temperate countries, sward targets have been defined in terms of sward height or forage mass, and experimental results have been directly applied to production systems (Hodgson, 1990; Matthews et al., 1999). Researchers of tropical areas already recognized the progress of this concept (Humphreys, 1997). In Brazil, there has been a growing interest in developing grazing management strategies based on descriptors of sward condition, and recent studies indicates that this concept could be applied to tropical pastures without great adaptations (Hodgson \& Silva, 2002).

In this paper, data presented in two previous papers (Andrade et al., $2006 \mathrm{a}, \mathrm{b}$ ) were integrated with the objective of defining sward management targets for mixed massaigrass and forage peanut pastures in the Western Brazilian Amazon. Seasonal variation in the carrying capacity of this pasture was also analyzed.

\section{Material and Methods}

This experiment was carried out at the Experimental Research Station of Embrapa Acre $\left(10^{\circ} 01^{\prime} 59^{\prime \prime} \mathrm{S}\right.$ and $\left.67^{\circ} 42^{\prime} 13^{\prime \prime} \mathrm{W}\right)$, in Rio Branco, AC, Brazil, between February 2002 and December 2003. Annual rainfall of 1,900 mm, a mean temperature of $25^{\circ} \mathrm{C}$ and $87 \%$ mean relative humidity characterize the local climate. The experimental area consisted of one $1,800 \mathrm{~m}^{2}$ area that was established in 1992 with massaigrass and planted with forage peanut (A.pintoi Ac 01) in 1994. The soil is classified as a Red-Yellow Argissol ( $\mathrm{pH} \mathrm{H}_{2} \mathrm{O}, 6.0$; $\mathrm{P}$ and $\mathrm{K}$ (Mehlich-1), 1.7 and $86.0 \mathrm{mg} /$ $\mathrm{dm}^{3} ; \mathrm{Ca}^{2+}$ and $\mathrm{Mg}^{2+}, 5.15$ and $0.83 \mathrm{cmol}_{\mathrm{c}} / \mathrm{dm}^{3} ; \mathrm{H}+\mathrm{Al}^{3+}$, $2.81 \mathrm{cmol}_{\mathrm{c}} / \mathrm{dm}^{3} ; \mathrm{SB}, 6.21 \mathrm{cmol}_{\mathrm{c}} / \mathrm{dm}^{3} ; \mathrm{CTCpH} 7.0,9.02 \mathrm{cmol}_{\mathrm{c}} / \mathrm{dm}^{3}$; $\mathrm{V}, 68.6 \%$; OM, $1.90 \mathrm{dag} / \mathrm{dm}^{3}$; clay, $18.3 \%$; silt, $24.5 \%$; sand, $57.2 \%)$. Triple super-phosphate $\left(50 \mathrm{~kg} / \mathrm{ha}\right.$ of $\left.\mathrm{P}_{2} \mathrm{O}_{5}\right)$ was added to the pasture in March 2002.

Sward condition was initially characterized by excessive forage mass $(9,500 \mathrm{~kg} /$ ha of drymatter $)$, thus the experimental area was submitted to a pre-experimental management from February to September of 2002. During this period, the experimental area was grazed by Nelore steers according to an intermittently stocking system with 35 days grazing cycle (2-d grazing period and $33-d$ rest period) at a daily herbage allowance of $15 \mathrm{~kg} D M / 100 \mathrm{~kg}$ live weight $(15 \% \mathrm{LW})$.

The experimental period started in October 2002, when the experimental area was subdivided in nine $200 \mathrm{~m}^{2}$ paddocks to implement the three daily herbage allowance levels of 7, 11 and 15\% LW, in a randomized complete block design with three replications. Throughout the experimental period (from October 2002 to December 2003) average daily herbage allowance levels actually applied were 9.0, 14.5 and $18.4 \%$ LW. Pastures were stocked with Nelore steers, averaging from 180 to $360 \mathrm{~kg}$ of body weight, observing an 
intermittent grazing system of 28 days grazing cycle (2-d grazing period and 26-d rest period) during the rainy season or of 35 days (2-d grazing period and 33-d rest period) during the dry season. Animals remained in experimental paddocks only during the 2-d grazing period, grazing an adjacent Brachiaria brizantha pasture during the rest period. Data from each grazing cycle were grouped into the following quarters: a) October-December, early rainy season; b) January-March, full rainy season; c) April-June, late rainy to early dry season; and, d) JulySeptember, full dry season.

Pre- and post-grazing sward condition (forage mass, sward height and percentage of bare ground), pre-grazing botanical composition (grass, legume and weeds), dry matter accumulation rates, defoliation intensity, grazing depth and grazed horizon were evaluated in each grazing cycle. The structure of massaigrass tussocks was characterized in both the dry and the rainy seasons. A complete description regarding the methodology used in the assessment of these parameters and data analysis were presented in two previous papers (Andrade et al., $2006 \mathrm{a}, \mathrm{b}$ ).

The approach used to define the sward management targets in the present study was to submit the mixed pasture to three daily herbage allowance levels $(9.0,14.5$ and $18.4 \%$ live weight), under intermittent stocking, in such a way as to establish different pre- and post-grazing sward conditions. The sward targets for this mixed pasture were thus established based on the sward condition that best conciliated the grass-legume balance, the maintenance of the structure of the grass tussocks and the equilibrium between the efficiencies of the first two steps of the animal production process under grazing: forage production and utilization. Sward targets were established for the periods of higher (October to May) and lower forage growth (June to September), similarly to what has been done in temperate countries (Hodgson, 1990; Matthews et al., 1999). Sward height (pre- and post-grazing) was the indicator chosen to define the sward targets recommended in this study, primarily because of its easiness of practical application in the real conditions of commercial farms.

In the present study, the carrying capacity (animal unit/ha) was determined according to the stocking rates applied to establish the daily herbage allowance determining the ideal (critical) sward condition. The annual carrying capacity in 2003 was calculated as the average stocking rate along the year. Also, the variation of stocking rates used in each grazing cycle permitted to establish the seasonal variation of the carrying capacity for this mixed pasture along the year 2003 .

\section{Results and Discussion}

The percentage of forage peanut associated with massaigrass was higher in shorter swards established by using lower herbage allowance(HA) levels, however higher pasture productivity was obtained in taller swards (Table 1). This finding is in accordance with the literature (Hernandez et al., 1995; Ibrahim \& Mannetje, 1998), and corroborates the analyses of Hodgson \& Silva (2002) considering that the definition of grazing management strategies for mixed pastures with forage peanut needs to strike a balance between the forage production advantages of a relatively lax grazing and the advantages to legume content of a relatively hard grazing.

Pasture grazed at $18.4 \% \mathrm{LW}$ was characterized by presenting high total DM production, however this was associated with low defoliation intensity and excessive sward height and forage mass, thus limiting the growth of forage peanut and causing the deterioration of the structure of the grass tussocks at the end of the experimental period (Table 1). The intermediate HA level $(14.5 \% \mathrm{LW})$ provided better balance among pasture productivity, defoliation intensity and maintenance of the structure of massaigrass tussocks, although the growth of forage peanut was still limited under this condition. Pasture grazed at $9.0 \% \mathrm{LW}$ allowed good growth of forage peanut and provided good control of the structure of the grass tussocks, with high proportion of green leaves at the end of the experimental period, but pasture productivity was reduced relative to the other treatments. In addition, at this HA level pasture showed increased percentage of bare ground (Andrade et al., 2006 a), an unwanted situation primarily in the Amazon region where cultivated pastures are usually under heavy biotic pressure caused by weeds (Dias-Filho, 2003). Considered all together, these results imply that the ideal sward condition for this mixed massaigrass-forage peanut pasture would be observed in swards managed under a HA level between 10 and $12 \% \mathrm{LW}$, which represents a sward condition intermediate between those observed for swards managed at the two lower HA levels.

The following sward targets can be recommended to guide the intermittent stocking management of mixed massaigrass-forage peanut pastures in the environmental conditions of the Western Brazilian Amazon: pre-grazing sward height ranging from $50-55 \mathrm{~cm}$ (June to September) to $65-70 \mathrm{~cm}$ (October to May), and post-grazing sward height from 30-35 cm (June to September) to 35-40 $\mathrm{cm}$ (October to May). Values suggested for the period of lower pasture growth (June to September) were different from those 
Table 1 - Summary of sward condition, botanical and morphological composition, productivity and utilization of a mixed massaigrass and forage peanut pasture, according to herbage allowance levels

\begin{tabular}{|c|c|c|c|}
\hline \multirow[t]{2}{*}{ Parameter } & \multicolumn{3}{|c|}{ Herbage allowance $(\%$ LW $)$} \\
\hline & 9.0 & 14.5 & 18.4 \\
\hline \multicolumn{4}{|l|}{ Sward height $(\mathrm{cm}){ }^{1}$} \\
\hline Pre-grazing & $51-65$ & $57-72$ & $66-82$ \\
\hline Post-grazing & $30-37$ & $37-42$ & $46-54$ \\
\hline \multicolumn{4}{|l|}{ Forage mass $(t / h a)$} \\
\hline Pre-grazing 1 & $3.4-4.6$ & $4.8-6.8$ & $5.4-8.0$ \\
\hline Post-grazing ${ }^{1}$ & $2.0-2.8$ & $3.4-4.0$ & $4.0-5.0$ \\
\hline Massaigrass 2 & 2.9 & 5.2 & 7.0 \\
\hline Forage peanut ${ }^{2}$ & 1.1 & 0.7 & 0.5 \\
\hline \multicolumn{4}{|l|}{ Botanical composition (\%) } \\
\hline Massaigrass & 63.2 & 76.1 & 86.2 \\
\hline Forage peanut & 23.5 & 10.6 & 6.4 \\
\hline Weeds & 13.3 & 13.3 & 7.4 \\
\hline \multicolumn{4}{|l|}{$\begin{array}{l}\text { Morphological composition } \\
\text { of massaigrass }(\%)^{3}\end{array}$} \\
\hline Green leaf lamina & 69 & 59 & 48 \\
\hline Pseudostem & 3 & 12 & 19 \\
\hline Dead material & 28 & 29 & 33 \\
\hline \multicolumn{4}{|l|}{ Productivity and utilization } \\
\hline Annual DM production $(\mathrm{t} / \mathrm{ha})$ & 20.4 & 26.8 & 29.2 \\
\hline Defoliation intensity (\%) & 42 & 36 & 35 \\
\hline Average stocking rate $(\mathrm{AU} / \mathrm{ha})$ & 3.0 & 2.5 & 2.3 \\
\hline
\end{tabular}

${ }^{1}$ Average sward condition in the driest (Jul/Sep 2003) and rainiest periods (Oct/Dec 2003), respectively.

2 Pre-grazing botanical composition in Oct/Dec 2003.

3 Pre-grazing morphological composition of massaigrass in Dec 2003.

established for the remaining of the year, mainly in the pregrazing condition. Results obtained in the present study showed that, even reducing stocking rates and increasing the rest period, pastures presented lower sward height and forage mass in this period, because of the lower pasture growth. Therefore, due to climatic variation among years, it is important that there is enough flexibility in using sward targets established for the pre-grazing condition, primarily during the months of transition between the considered periods (May/Jun and Sep/Oct).

Although an important consideration about the use of these sward targets concerns animal performance, it was not directly included in the definition of the sward targets since it could not be measured. There is no reported study suggesting sward targets or HA levels for pure or mixed massaigrass pastures. For continuously stocked Panicum maximum cv. Tanzânia pastures, a HA level between 8 and $11 \% \mathrm{LW}$, based on green leaf mass, assured good animal performance and productivity (Barbosa et al., 2001). In another study, under intermittent stocking, it was suggested the use of a daily HA level above $6 \% \mathrm{LW}$ (as green leaf mass) to assure better beef cattle performance on tanzaniagrass pastures (Penati, 2002). The lower HA level suggested for intermittently stocked pastures probably reflects the differences between the grazing methods in the calculation of herbage allowance (Pedreira, 2002). In intermittently stocked temperate pastures, herbage intake and animal performance increase at declining rates with increasing HA level, usually reaching a plateau at a daily HA level equal to $10-12 \%$ LW for most classes of stock (Hodgson, 1990). Despite these last data may suggest that the sward targets defined according to an $\mathrm{HA}$ level between 9.0 and $14.5 \% \mathrm{LW}$ (equivalent to $11.7 \% \mathrm{LW}$ ) should assure satisfactory animal performance on mixed massaigrass and forage peanut pastures, the proposed sward targets should be considered as a first approximation to an advanced grazing management strategy for this mixture in the Western Brazilian Amazon. Ideally, these sward targets should be refined by additional studies planned to provide information about its relationship with animal performance.

The annual carrying capacity of this mixed pasture in 2003 was estimated to be $2.7 \mathrm{AU} / \mathrm{ha}$, varying from 1.8 to 3.6 $\mathrm{AU} / \mathrm{ha}$, in the dry (Apr/Sep) and the rainy (Oct/Mar) seasons, respectively. These values are very good, considering that the pasture had never received chemical nitrogen fertilizer since it was established 12 years ago. Certainly, the contribution of the nitrogen biologically fixed by forage peanut was an important factor, as well as the high forage production capacity of massaigrass (Lempp et al., 2001; Valentim et al., 2001). In clipped studies, the annual DM production of massaigrass was 16 and $12 \%$ higher when compared with cultivars Tanzânia and Mombaça, respectively (Valentim \& Moreira, 1994). In the Brazilian Cerrado, massaigrass also presented higher carrying capacity during the rainy season than tanzaniagrass and mombaçagrass (Brâncio, 2003).

Pasture carrying capacity depends on many factors such as climate, soil, management and species productivity (Gomide et al., 2001). Thus, it must be emphasized that the values obtained in the present work are specific for the year 2003, and for the soil, paddock size and grazing management conditions of this study, and consequently could not be extrapolated directly to other pastures of the region. However, the analysis of the seasonal variation in the carrying capacity presented by this mixed pasture can be used as a starting point for planning animal production systems in the region, especially in relation to feed budget on farms.

Seasonal variation in carrying capacity, in DM accumulation rates and in rainfall in the Municipal district of Rio Branco-AC, through the year 2003, are shown in Figure 1. As expected, seasonal variation in carrying capacity followed a trend very similar to that of pasture productivity $(\mathrm{r}=0.92)$, although the correlation with rainfall was inferior $(\mathrm{r}=0.50)$. The association between carrying capacity and 
pasture productivity was especially high during the period of higher pasture growth (October to April). With the onset of the dry season, carrying capacity decreased less than pasture productivity, evidencing a certain buffering capacity from the accumulated forage mass. Overall, carrying capacity during the dry season was equivalent to $50 \%$ of that estimated for the rainy season.

When carrying capacity data from each grazing cycle were regressed against the respective DM accumulation rate data, a well-fitted linear equation was obtained (Figure 2), indicating that DM accumulation rate accounted for $85 \%$ of the variation in carrying capacity. The equation also indicated that carrying capacity increased $1.0 \mathrm{AU} /$ ha per each increase of $29.07 \mathrm{~kg} / \mathrm{ha} /$ day in pasture DM accumulation rate.

It is interesting to notice that higher pasture productivity and carrying capacity were observed in Oct/Dec, in comparison with Jan/Mar (Figure 1A), although higher rainfall was observed in Jan/Mar (Figure 1B). This finding is in line with the observations of farmers and researchers in the region. In mixed pastures with $A$. pintoi $\mathrm{cv}$. Amarillo and several Brachiaria species, established in a site with annual

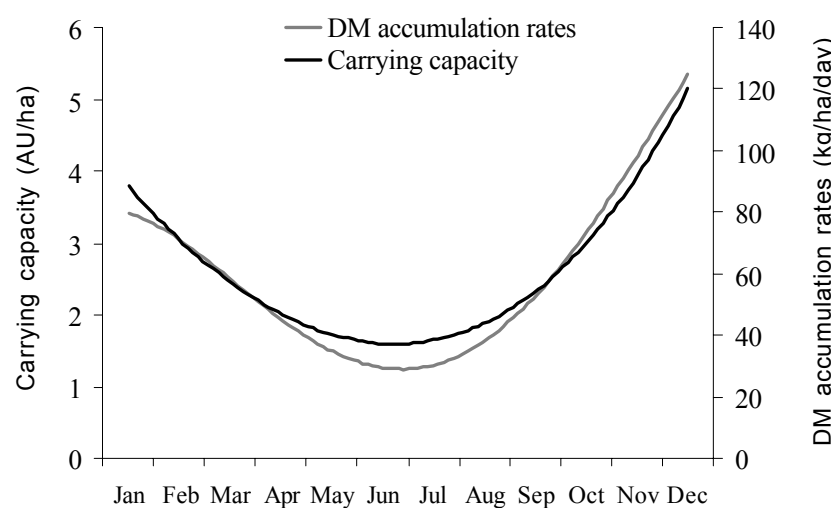

A

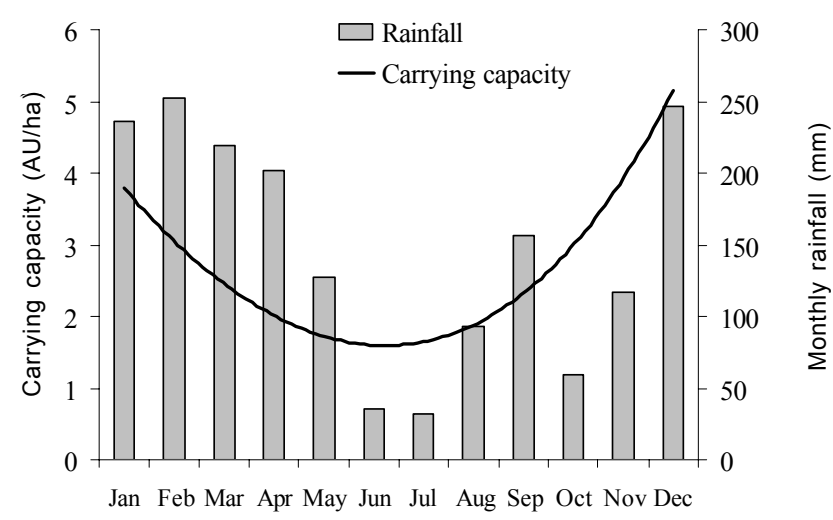

B

Figure 1 - Seasonal variation of carrying capacity and DM accumulation rates in the mixed experimental pasture (A) and monthly rainfall (B) at Rio Branco, AC, Brazil, through the year 2003.

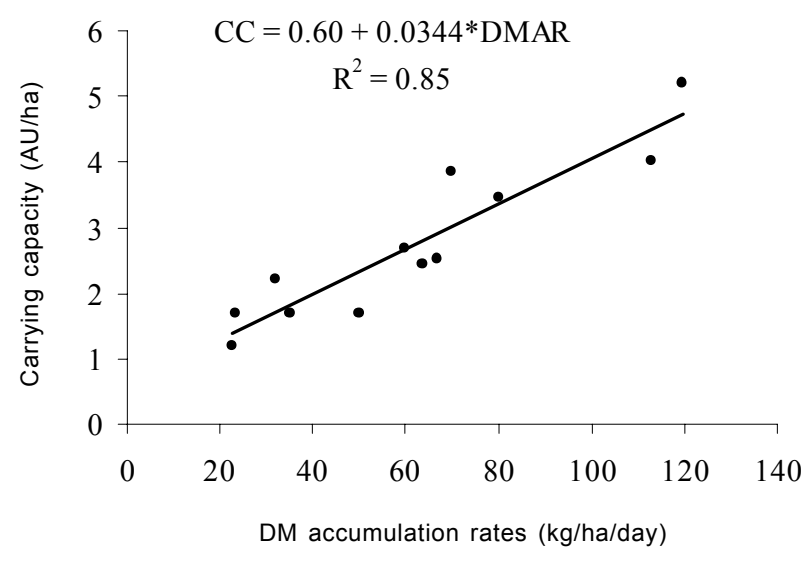

Figure 2 - Relationship of pasture carrying capacity and DM accumulation rates in the intermittently stocked massaigrass and forage peanut pasture throughout 2003. * Significant by $\mathrm{F}$ test at the $5 \%$ level.

rainfall of 2,300 $\mathrm{mm}$ in Colombia, higher DM accumulation rates also happened during the first quarter of the rainy season(Grof, 1985). Also in Colombia, lowerDMaccumulation rates in mixed pastures (Brachiaria spp., A. pinto $i$ and $D$. ovalifolium) were measured during the three months of highest rainfalls (Fisher \& Cruz, 1995). For these authors, this finding could be related to: a) lower radiation levels, due to the cloudy whether; b) damages caused to the plants by the trampling of the grazing animals on the very wet soils; and c) nutritional problems associated with waterlogged soils.

In the state of Acre, although mean temperatures were similar $\left(25^{\circ} \mathrm{C}\right)$ in both periods, historically the number of solar radiation hours during the Oct/Dec period is $25 \%$ higher than in Jan/Mar, a period when a cloudy weather is quite intense. Another possible factor involved could be a higher nitrogen availability for pasture growth at the beginning of the rainy season, due to the decomposition of organic residues that were deposited on the soil during the dry season, especially in the case of grass-legume pastures, because legumes such as $A$. pintoi generally shed part of their leaves during the dry season in response to water deficit (Ludlow, 1980; Fisher \& Cruz, 1995).

\section{Conclusions}

For the Western Brazilian Amazon conditions, the following sward management targets can be recommended as a first approximation to a good management of mixed massaigrass-forage peanut pastures under intermittent stocking: pre-grazing height ranging from $50-55 \mathrm{~cm}$ (June to September) to $65-70 \mathrm{~cm}$ (October to May), and post-grazing height from 30-35 cm (June to September) to $35-40 \mathrm{~cm}$ (October to May). 


\section{Literature Cited}

ANDRADE, C.M.S.; GARCIA, R.; VALENTIM, J.F. et al. Grazing management strategies for massaigrass-forage peanut pastures. 1. Dynamics of sward condition and botanical composition Revista Brasileira de Zootecnia, v.35, n.2, p.334-342, 2006a.

ANDRADE, C.M.S.; GARCIA, R.; VALENTIM, J.F. et al. Grazing management strategies for massaigrass-forage peanut pastures. 2. Productivity, utilization and sward structure. Revista Brasileira de Zootecnia, v.35, n.2, p.343-351, 2006b.

BARBOSA, M.A.A.F.; NASCIMENTO JR., D.; CECATO, U. et al. Desempenho de novilhos em capim tanzânia com diferentes ofertas de forragem. In: REUNIÃO ANUAL DA SOCIEDADE BRASILEIRA DE ZOOTECNIA, 38., 2001, Piracicaba. Anais... Piracicaba: Sociedade Brasileira de Zootecnia, 2001. 1 CD-ROM

BODDEY, R.M.; SÁ, J.C.M.; ALVES, B.J.R. et al. The contribution of biological nitrogen fixation for sustainable agricultural systems in the tropics. Soil Biology and Biochemistry, v.29, n.5/6, p.787-799, 1997.

BRÂNCIO, P.A.; NASCIMENTO JR., D.; EUCLIDES, V.P.B. et al. Avaliação de três cultivares de Panicum maximum Jacq. sob pastejo: composição da dieta, consumo de matéria seca e ganho de peso animal. Revista Brasileira de Zootecnia, v.32, n.5, p.1037-1044, 2003

BRISKE, D.D.; HEITSCHMIDT, R.K. An ecological perspective. In: HEITSCHMIDT, R.K.; STUTH, J.W. (Eds.) Grazing management: an ecological perspective. Portland: Timber Press, 1991. p.11-26.

CRUZ, P.A.; SINOQUET, H. Competition for light and nitrogen during a regrowth cycle in a tropical forage mixture. Field Crops Research, v.36, p.21-30, 1994

DIAS-FILHO, M.B. Degradação de pastagens: processos, causas e estratégias de recuperação. Belém: Embrapa Amazônia Oriental, 2003. 152p

FISHER, M.J.; CRUZ., P. Algunos aspectos de la ecofisiología de Arachis pintoi. In: KERRIDGE, P.C. (Ed.) Biología y agronomia de especies forrajeras de Arachis. Cali: CIAT, 1995. p.56-75.

FISHER, M.J.; RAO, I.M.; THOMAS, R.J. et al. Grasslands in the well-watered tropical lowlands. In: HODGSON, J.; ILLIUS, A.W. (Ed.) The ecology and management of grazing systems. Wallingford: CAB International, 1996. p.393-425.

GOMIDE, J.A.; WENDLING. I.J.; BRAS, S.P. et al. Consumo e produção de leite de vacas mestiças em pastagem de Brachiaria decumbens manejada sob duas ofertas diárias de forragem. Revista Brasileira de Zootecnia, v.30, n.4, p.1194-1199, 2001

GROF, B. Forage attributes of the perennial groundnut Arachis pintoi in a tropical savanna environment in Colombia. In: INTERNATIONAL GRASSLAND CONGRESS, 15., 1985, Kyoto. Proceedings... Nishi-Nasuno: Japanese Society of Grassland Science, 1985. p.168-170

HERNANDEZ, M.; ARGEL, P.J.; IBRAHIM, M.A. et al. Pasture production, diet selection and liveweight gains of cattle grazing Brachiaria brizantha with or without Arachis pintoi at two stocking rates in the Atlantic Zone of Costa Rica. Tropical Grasslands, v.29, p.134-141, 1995.

HODGSON, J. The significance of sward characteristics in the management of temperate sown pastures. In: INTERNATIONAL GRASSLANDS CONGRESS, 15., 1985, Kyoto. Proceedings... Nagoya: Japanese Society of Grassland Science, 1985. p.63-66.

HODGSON, J. Grazing management: science into practice. Harlow: Longman Scientific \& Technical, 1990. 203p.

HODGSON, J.; SILVA, S.C. Sustainability of grazing systems: goals, concepts and methods. In: LEMAIRE, G.; HODGSON, J.; MORAES, A. et al. (Eds.) Grassland ecophysiology and grazing ecology. Wallingford: CAB International, 2000. p.1-13.

HODGSON, J.; SILVA, S.C. Options in tropical pasture management. In: REUNIÃO ANUAL DA SOCIEDADE BRASILEIRA DE ZOOTECNIA, 39., 2002, Recife. Anais... Recife: Sociedade Brasileira de Zootecnia, 2002. p.180-202.
HUMPHREYS, L.R. The evolving science of grassland improvement. Cambridge: Cambridge University Press, 1997. 261p.

IBRAHIM, M.A.; MANNETJE, L.'t. Compatibility, persistence and productivity of grass-legume mixtures in the humid tropics of Costa Rica. 1. Dry matter yield, nitrogen yield and botanical composition. Tropical Grasslands, v.32, n.2, p.96-104, 1998.

LASCANO, C.E. Valor nutritivo y producción animal de Arachis forrajero. In: KERRIDGE, P.C. (Ed.) Biología y agronomia de especies forrajeras de Arachis. Cali: CIAT, 1995. p.117-130.

LASCANO, C.E. Selective grazing on grass-legume mixtures in tropical pastures. In: LEMAIRE, G.; HODGSON, J.; MORAES, A. et al. (Eds.) Grassland ecophysiology and grazing ecology. Wallingford: CAB International, 2000. p.249-263.

LEMPP, B.; SOUZA, F.H.D.; COSTA, J.C.G. et al. Capim-massai (Panicum maximum cv. Massai): alternativa para diversificação de pastagens. Campo Grande: Embrapa Gado de Corte, 2001. 9p. (Comunicado Técnico, 69)

LUDLOW, M.M. Stress physiology of tropical pasture plants. Tropical Grasslands, v.14, n.3, p.136-145, 1980.

MATTHEWS, P.N.P.; HARRINGTON, K.C.; HAMPTON, J.G. Management of grazing systems. In: WHITE, J.; HODGSON, J. (Ed.) New Zealand Pasture and Crop Science. Auckland: Oxford University Press, 1999. p.153-174.

PARSONS, A.J.; LEAFE, E.L.; COLLETT, B. et al. The physiology of grass production under grazing. II. Photosynthesis, crop growth and animal intake of continuously-grazed swards. Journal of Applied Ecology, v.20, p.127-139, 1983.

PEDREIRA, C.G.S. Avanços metodológicos na avaliação de pastagens. In: REUNIÃO ANUAL DA SOCIEDADE BRASILEIRA DE ZOOTECNIA, 39., 2002, Recife. Anais... Recife: Sociedade Brasileira de Zootecnia, 2002. p.100-150.

PENATI, M.A. Estudo do desempenho animal e produção do capim Tanzânia (Panicum maximum Jacq.) em um sistema rotacionado de pastejo sob irrigação em três níveis de resíduo pós-pastejo. Piracicaba: Escola Superior de Agricultura Luiz de Queiroz, 2002. 117p. Tese (Doutorado em Agronomia) - Escola Superior de Agricultura Luiz de Queiroz, 2002.

SPAIN, J.M. O uso de leguminosas herbáceas nas pastagens tropicais. In: PEIXOTO, A.M.; MOURA, J.C.; FARIA, V.P. (Eds.) Plantas Forrageiras de Pastagens. Piracicaba: Fundação de Estudos Agrários Luiz de Queiroz, 1995. p.275-299.

THOMAS, R.J. The role of the legume in the nitrogen cycle of productive and sustainable pastures. Grass and Forage Science, v.47, p.133-142, 1992.

THOMAS, R.J. Roles of legumes in providing $\mathrm{N}$ for sustainable tropical pasture systems. Plant and Soil, v.174, n.1-2, p.103$118,1995$.

VALENTIM, J.F.; ANDRADE, C.M.S. Perspectives of grass-legume pastures for sustainable animal production in the tropics. In: REUNIÃO ANNUAL DA SOCIEDADE BRASILEIRA DE ZooteCniA, 40., 2004, Campo Grande. Anais... Campo Grande: Sociedade Brasileira de Zootecnia, 2004. p.142-154.

VALENTIM, J.F.; CARNeIRO, J.C.; MOREIRA, P. et al. Capimmassai (Panicum maximum Jacq.): nova forrageira para a diversificação das pastagens no Acre. Rio Branco: Embrapa Acre, 2001. 16p. (Circular Técnica, 41)

VALENTIM, J.F.; MOREIRA, P. Adaptação, produtividade, composição morfológica e distribuição estacional da produção de forragem de ecotipos de Panicum maximum no Acre. Rio Branco: Embrapa Acre, 1994. 24p. (Boletim de Pesquisa, 11)
Recebido: 03/11/04 Aprovado: 02/12/05 